\title{
Settlement of megalopae and early juveniles of the velvet swimming crab Necora puber (Decapoda: Portunidae) in flow conditions
}

\author{
James T. Lee ${ }^{1}$, John Widdows ${ }^{2}$, Malcolm B. Jones ${ }^{1}$, Ross A. Coleman ${ }^{1, *}$ \\ ${ }^{1}$ Marine Biology and Ecology Research Group, School of Biological Sciences, University of Plymouth, Plymouth PL4 8AA, UK \\ ${ }^{2}$ Plymouth Marine Laboratory, Prospect Place, West Hoe, Plymouth PL1 3DH, UK
}

\begin{abstract}
Settlement is a critical period in the life cycle of crabs and can be a major factor influencing the structure of local populations. Under natural conditions, tidal stream velocities commonly exceed swimming capabilities of postlarvae and can affect settlement onto favourable habitats. In an annular flume simulating natural flow velocities, the diel variability of megalopal distribution, and the ontogenetic change in habitat use of young juveniles of the velvet swimming crab Necora puber were examined simultaneously on 4 substrata of different structural complexity (a red macroalga, pebbles, artificial grass and sand). The distribution of dead animals was non-even and higher numbers occurred on complex substrata. Live animals showed a positive response to the macroalga and pebbles, causing an increase in settlement compared to the passive distribution of dead animals. In contrast, numbers of settlers on artificial grass were significantly lower than for dead animals. Differences in the pattern of distribution between day and night suggested that megalopae were less selective during the day, and avoidance of Astroturf tended to be stronger at night. Although megalopae and early juveniles show capability of active selection of substrata, the differential distribution on natural substrata during settlement was most likely set by hydrodynamic conditions; active movement may only occur when a substratum of lower suitability is encountered.
\end{abstract}

KEY WORDS: Substratum · Postlarvae $\cdot$ Settlement behaviour $\cdot$ Habitat selection $\cdot$ Flume Resale or republication not permitted without written consent of the publisher

\section{INTRODUCTION}

The first step in determining processes controlling the recruitment of benthic organisms is understanding the variation in the arrival of settlers. This includes (1) production of larvae, (2) their dispersal in the plankton, (3) the risk of mortality while dispersing, and (4) the settlement of larvae (Underwood \& Keough 2001). For meroplanktonic animals, the transition to the benthos (or settlement) is a critical period in their life cycle, and can be a major influence on the structure of local populations (Underwood \& Fairweather 1989).

Settlement of crabs, like many benthic invertebrates, can be influenced by chemical and/or physical cues, including surface texture or chemistry and presence of microbial films or other benthic species (see reviews by Pawlik 1992, Rittschof et al. 1998). Blue crab Callinectes sapidus megalopae avoid odours from potential predators (Welch et al. 1997, Diaz et al. 1999), and modify swimming behaviour according to turbulence and presence of odours from nursery area vegetation (Welch et al. 1999, Welch \& Forward 2001, Forward et al. 2003). Similarly, megalopae of the porcelain crabs Petrolisthes cinctipes and $P$. eriomerus have aggregated settlement with adults in response to conspecific chemical cues (Jensen 1989, 1991).

Although crabs and lobsters settle in a wide variety of habitats (Cobb et al. 1997, Booth 2001), settlement occurs primarily onto structurally complex habitats, such as oyster shells (Fernandez et al. 1993), macroal- 
gae (Hedvall et al. 1998), hydroids (Stevens 2003), gravel (Stevens \& Kittaka 1998) and cobble (Linnane et al. 2000). High levels of mortality during settlement or soon after are observed widely in marine invertebrates and can substantially alter the distribution of recruits and the structure of the population (Gosselin \& Qian 1997, Hunt \& Scheibling 1997). Settling in an unfavourable habitat that provides poor shelter could lead to high predation as reported for crabs (Eggleston \& Armstrong 1995, Pile et al. 1996, Moksnes et al. 1998, Loher \& Armstrong 2000, Luppi et al. 2001) and lobsters (Incze \& Wahle 1991, Wahle \& Steneck 1991, 1992, Cobb \& Wahle 1994).

Despite decapod postlarvae generally being strong swimmers (Cobb et al. 1989, Luckenbach \& Orth 1992, Fernandez et al. 1994), tidal stream velocities commonly exceed their swimming capabilities and during the postlarval stage, flow plays a major role in dispersal. Flow can affect settlement of marine organisms at different levels (see reviews by Butman 1987, Abelson \& Denny 1997). Firstly, it may exert hydrodynamic forces on settlers, affecting encounters with substrata and behaviours following encounter (e.g. Pawlik \& Butman 1993). Secondly, flow may act as a settlement cue which induces active behaviour of settlers; recent advances in the understanding of the mechanisms controlling selective flood-tide transport have demonstrated the importance of turbulence (Forward \& Tankersley 2001). Finally, flow may be a modifying factor affecting the various settlement cues mentioned above.

The velvet swimming crab Necora puber (L.) is abundant in the shallow waters of British rocky shores (Ingle 1983), with juveniles being found commonly in the lower intertidal (Choy 1986, Norman 1989). We have found megalopae and juvenile N. puber in pebbled/cobbled areas and in coarse sand, but more usually in turf algae such as Mastocarpus stellatus (Stackhouse) Guiry (J.T.Lee et al. unpubl. data). The ecology of the benthic adult has been examined (e.g. Gonzalez-Gurriaran 1985a,b, Choy 1988, Norman \& Jones 1992, 1993, Gonzalez-Gurriaran et al. 1995, Freire et al. 1996). However, there is limited understanding of the planktonic phase of the life cycle of $N$. puber, despite the classical works of Lebour $(1928,1947)$. There are some reports on larval biology (AlvarezOssorio et al. 1990, Choy 1991, Mene et al. 1991, Valdes et al. 1991) and postlarval ecology (e.g. Lindley $1986,1987)$, but none, to our knowledge, on the transition from pelagic to benthic periods during the life history of this crab.

To increase understanding of the integration of these environments, and the processes controlling the abundance and distribution of benthic populations of $\mathrm{NeC}$ ora puber, it is essential to determine the processes involved in the initial distribution of settlers. As illus- trated above, the former is a direct consequence of water flow conditions and larval behaviour; therefore, we have investigated (1) the effect of flow in the passive distribution of settlers, (2) the active component during settlement of megalopae and early juveniles of $N$. puber under hydrodynamic conditions, (3) the change in habitat use by first juvenile instars, and (4) the diel variation in the settlement pattern of megalopae.

\section{MATERIALS AND METHODS}

Collection and maintenance of specimens. Megalopae were collected from Plymouth Sound, UK $\left(50^{\circ} 22^{\prime} \mathrm{N}, 04^{\circ} 11^{\prime} \mathrm{W}\right), 2$ to $3 \mathrm{~d}$ prior to the trial runs. A plankton net (mesh size $500 \mu \mathrm{m}$ ) was towed for approximately $5 \mathrm{~min}$ in surface waters and specimens were transported to the laboratory in an iced cool box immediately after collection. In the laboratory, animals were maintained in a temperature-controlled room at $15 \pm$ $1^{\circ} \mathrm{C}$, under $14: 8 \mathrm{~h}$ light:dark conditions, with approximately $1 \mathrm{~h}$ of diffuse light at dusk and dawn (close to natural conditions at Plymouth during this period of the year). Animals were fed ad libitum with newly hatched nauplii of Artemia sp. and kept under these conditions for at least $48 \mathrm{~h}$ before experiments were carried out. First juvenile instars of Necora puber were cultivated from wild megalopae and fed newly hatched nauplii of Artemia sp. Only first or second juvenile instars were used; we refer to these as 'juveniles'.

Flow tank. All experiments were carried out using an annular flume constructed of acrylic material (full description is given by Widdows et al. 1998). The external diameter was $64 \mathrm{~cm}$ and the water channel dimensions were $10 \mathrm{~cm}$ width by $40 \mathrm{~cm}$ height (Fig. 1). Flow was induced by a rotating annular drive plate on the surface of the water at a height of $20 \mathrm{~cm}$ above the substrata. The most important benefit of an annular over a linear flume is a continuous system where megalopae can face a flow regime for many hours, as experienced in the natural environment. Due to the curvature of the channel, small differences in flow in the inner and outer walls of the flume may cause minor secondary radial flows; nonetheless, these can be minimized by reducing the channel width (see Fukada \& Lick 1980). Current velocity was measured in the middle of the channel, $10 \mathrm{~cm}$ above the substratum, using an electromagnetic current flow meter (Valeport Model 800-175) inserted via a port in the base of the flume. Flow measurements were taken after the trials to avoid interference of the probe with the settlement behaviour. At the rotating plate speed used (34 rpm), and with the addition of substrata, the flume generated 
a current velocity of ca. $6 \mathrm{~cm} \mathrm{~s}^{-1}$, which is broadly representative of benthic conditions in Plymouth Sound at neap tides.

Hypotheses tested. The main purpose of the study was to determine the factors affecting substratum selection of megalopae and early juveniles of Necora puber under flow conditions. We tested the following hypotheses: (1) Passive deposition of megalopae or early juveniles creates a non-even distribution. Passive distribution of dead animals was tested against the null hypothesis of an even distribution to determine the importance of flow on the dispersal of settlers. (2) Passive deposition differs from active settlement for each developmental stage. Distribution of live animals was tested against dead ones to provide the extent of active substratum selection. In both the tests above, dead crabs were used, as these are identical to live crabs in terms of cross-sectional area, drag and buoyancy but without the ability to cling. (3) Substratum selection amongst megalopae and early juveniles differs. Distribution of live megalopae was tested against distribution of live early juveniles to determine ontogenetic variation of settlement selection. (4) Substratum selection of megalopae varies according to time of day. Distribution of animals at night was tested against distribution from daytime to examine possible diel differences in selection or strategies during settlement. Evidence from the blue crab Callinectes sapidus showed no difference in planktonic dispersal between day and night for first and second instars, and only a tendency for greater dispersal at night for third through fifth instars (Blackmon \& Eggleston 2001); thus, only night trials were run for live juveniles.

Experimental design. Trials were carried out during the summer and autumn of 2002 at the Plymouth Marine Laboratory, Plymouth, UK. The employed design followed the pioneering study of Hedval et al. (1998) using an annular flume. Four substrata of differing structural complexities were chosen for the study: (1) A red macroalga Mastocarpus stellatus with a complex 3D structure, hereafter referred to as 'alga'. This alga is reasonably abundant on the rocky shores where early juveniles are commonly found; further details of $M$. stellatus can be found in Hiscock (1986). It was chosen as a natural complex structure that represents the substrata of the lower intertidal area, and also possessed biotic cues. Individual branches of the alga were attached to a mesh to create a uniform height of $5 \mathrm{~cm}$ and stems were evenly distributed ca. $2 \mathrm{~cm}$ apart. This density was lower than on the shore, but was chosen due to the logistics of frequently replacing decaying or damaged branches. (2) Artificial grass (Astroturf ${ }^{\mathrm{TM}}$ ), with 'leaves' $2 \mathrm{~cm}$ long, $2 \mathrm{~mm}$ wide and ca. 1 to $2 \mathrm{~mm}$ apart was chosen as a habitat with complex structure that lacked biotic chemical cues. Preliminary studies had shown that megalopae and juvenile Necora puber could get between the blades. Mats were washed in hot water, then soaked in filtered seawater $(1 \mu \mathrm{m})$ for $5 \mathrm{~d}$ prior to the experiment to minimise traces of manufacturing chemicals. (3) Pebbles, ranging from 2 to $6 \mathrm{~cm}$ diameter, were collected from the intertidal area. This substratum was chosen as a structurally less complex habitat. (4) Sand, an unstructured habitat, was collected from the same intertidal area, and sieved through a $2 \mathrm{~mm}$ mesh-size sieve to remove small pebbles. Substrata 3 and 4 were thoroughly hand-cleaned of visible biota, washed in hot water and air-dried.

The bottom of the flume channel was divided into 4 sections and each was covered with 1 of the substrata (Fig. 1a). The circular arrangement of the 4 substrata was permutated in 6 different ways, minimising the possible effect of the order of the substrata; each treatment was replicated with all 6 possible permutations, except the dispersal of dead megalopae where 5 replicates were performed. Flow velocity used was ca. $6 \mathrm{~cm} \mathrm{~s}^{-1}$, below the velocity in which sand erosion was observed. To reduce additional turbulence incurred by differences in height from the edges of the substrata, Astroturf, which was the lowest in height, was raised by adding acrylic plates underneath. To give clear differences in substrata, $6 \mathrm{~cm}$ gaps were left between sections and covered with an acrylic plate at the same horizontal level of the substrata. Rotation of the flume drive plate was initiated at least $30 \mathrm{~min}$ prior to specimens being introduced through the gap between the rotating lid and the flume outer wall; 40 specimens per trial were released, 10 on top of each substratum whilst the flume was running. Tests of nocturnal settlement were initiated shortly after natural dusk time and lasted for $9 \mathrm{~h}$. Daytime experiments started around midday and lasted $6 \mathrm{~h}$. At the end of each experiment, acrylic plates were placed vertically amongst the substrata sections to avoid movement of megalopae or crabs during removal of substrata for counts.

Passive deposition was tested using freshly anaesthetised and killed animals, as previous trials have shown sinking rates to differ from those of preserved specimens. Runs lasted for only $2 \mathrm{~h}$ to avoid any changes in sinking rate due to decomposition of specimens.

Data analysis. Due to the occurrence of nil values, data were $(x+1)$-transformed to permit the taking of ln values. A replicated goodness-of-fit test (Sokal \& Rohlf 1995) was used to compare proportions of settlement on the substrata. When the null hypothesis of pooled data was rejected, an additional analysis was performed excluding the substratum, with highest contribution to the $G$-value, and the level of p was adjusted accordingly (Sokal \& Rohlf 1995). In addition, the net 


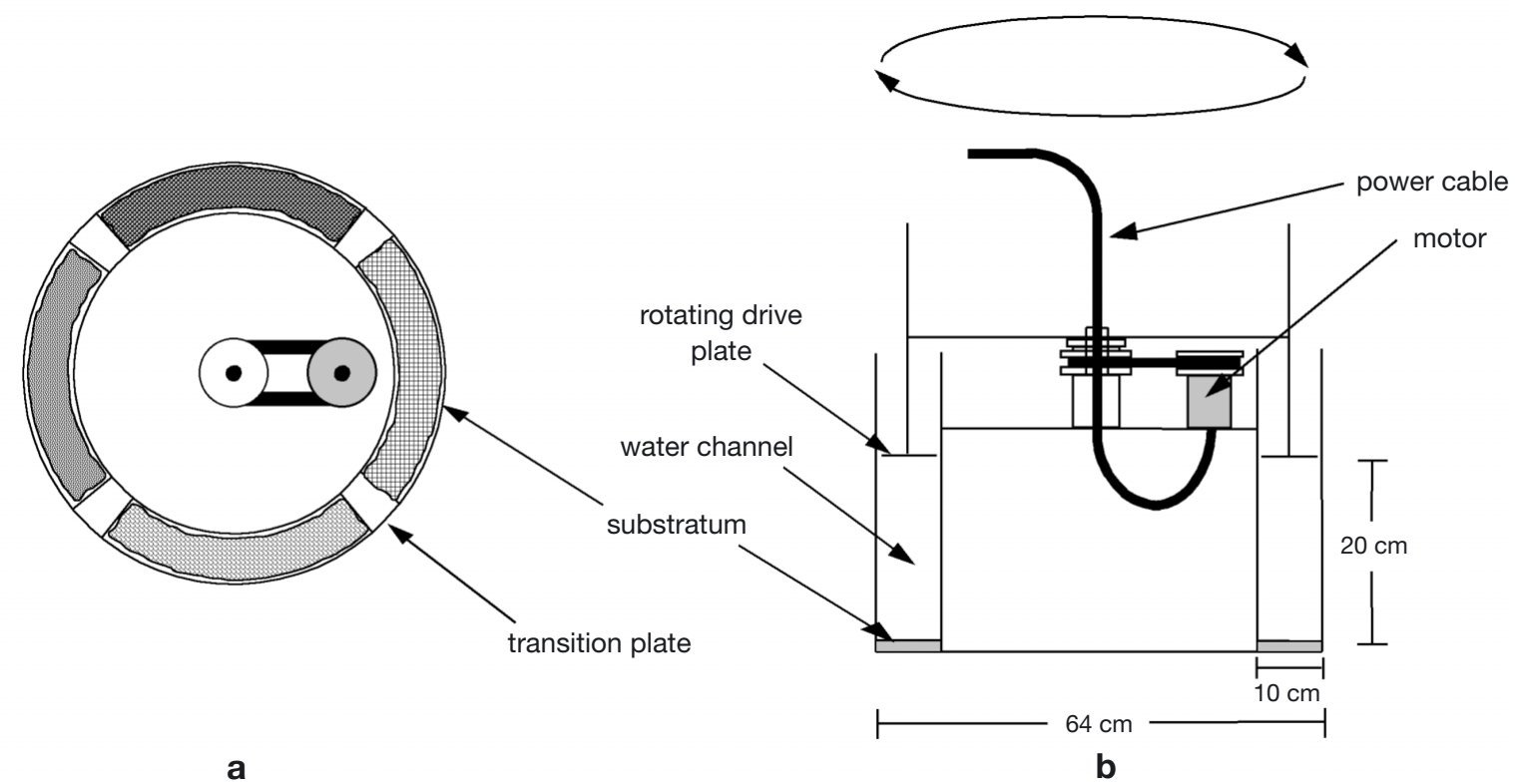

Fig. 1. Schematic diagram of the annular flume. (a) Top view of substrata arrangement. Shadings indicate differences in substrate types; all possible combinations of substrate type were used in the experiment. (b) Side view of the annular flume

response (residuals obtained by subtracting passive deposition of dead animals from distribution of live specimens) from pairing trials with identical substrata arrangement was calculated for each substratum at each time of day tested.

\section{RESULTS}

\section{Observation of swimming}

Usually, deposition of dead megalopae took less than $1 \mathrm{~min}$, while dead juveniles sank within $10 \mathrm{~s}$. On some occasions, dead me galopae were carried for a distance over the sand section before they stopped; this secondary transport was not observed on the other substrata or with dead juveniles. Most live megalopae settled within 1 to 2 min after being introduced to the flume, but it was common for a few individuals (1 to 5) to swim throughout the trial. Megalopae swam in short horizontal bursts; some maintained position or at times moved against the flow for up to $4 \mathrm{~s}$, with a tendency to swim upwards. However, most were carried with the flow and settled during the experiment; few animals were observed swimming after $6 \mathrm{~h}$. At the end of night trials, after separation plates were placed among the substrata and light was used, some megalopae appeared to show positive phototaxis. No juvenile was found swimming at the end of trials, and all settled within a few seconds after being introduced to the flume.

\section{Substrata selection}

On average, the recovery rate of dead megalopae and juveniles was above $99 \%$; likewise, that of live megalopae and juveniles was above $97 \%$. Moulting from megalopa to juvenile crab instar occurred on all night runs, ranging from 1 to 10 individuals, which suggests that megalopae used in the experiment were competent to metamorphose and ready to settle.

The dispersal pattern of dead animals was significantly heterogeneous amongst replicates. Results from pooled data showed that, under the hydrodynamic conditions tested, a non-even distribution of the dead megalopae was produced (Table 1, Fig. 2). Settlement

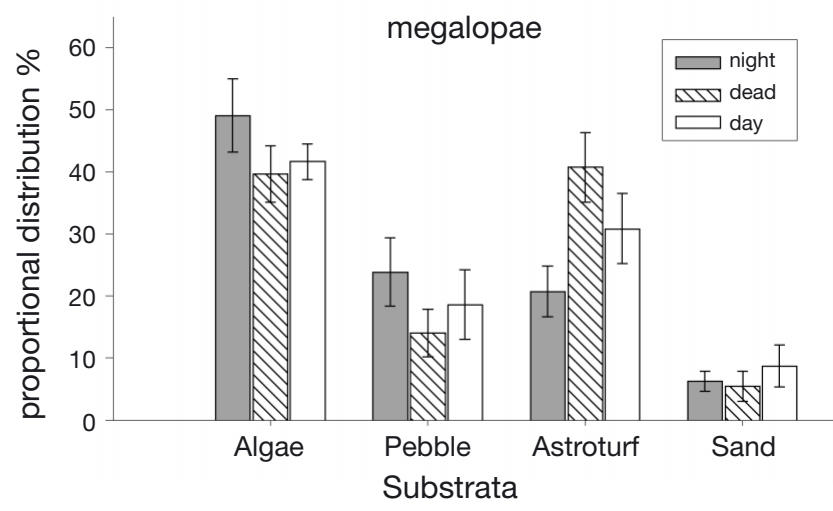

Fig. 2. Necora puber. Mean proportion of dead megalopae, megalopae during daytime and nighttime for each substratum $( \pm$ SEM) 
Table 1. Necora puber. Summary of replicated goodness-of-fit tests (Sokal \& Rohlf 1995) to test the null hypothesis of even distribution. Data were $(x+1)$ transformed to remove zeros. Each replicate was tested separately, followed by the test of all data $\left(G_{\text {Total }}\right)$, pooled data $\left(G_{\text {Pool }}\right)$, and the test of heterogeneity $\left(G_{\text {Het }}\right)$. The distributions of Meg(dead) = dead megalopae and Juv(dead) = dead juveniles were tested against the extrinsic hypothesis of Even = even distribution. ${ }^{*} \mathrm{p}<0.05,{ }^{* *} \mathrm{p}<0.01,{ }^{* * *} \mathrm{p}<0.001, \mathrm{~ns}$ : $\mathrm{p}>0.05$

\begin{tabular}{|c|c|c|c|c|c|c|c|c|c|c|}
\hline \multirow[t]{2}{*}{ Distribution } & & & & \multicolumn{4}{|c|}{ Replicates } & \multirow[t]{2}{*}{$G_{\text {Total }}$} & \multirow[t]{2}{*}{$G_{\text {Pool }}$} & \multirow[t]{2}{*}{$G_{\mathrm{Het}}$} \\
\hline & & 1 & 2 & 3 & 4 & 5 & 6 & & & \\
\hline \multirow{3}{*}{ Meg(dead) vs Even } & df & 3 & 3 & 3 & 3 & 3 & & 15 & 3 & 12 \\
\hline & $G$ & 18.8 & 4.1 & 26.8 & 16.8 & 32.4 & & 99.0 & 76.8 & 22.2 \\
\hline & $\mathrm{p}$ & $* * *$ & $\mathrm{~ns}$ & $* * *$ & $* * *$ & $* * *$ & & $* * *$ & $* * *$ & $* * *$ \\
\hline \multirow{3}{*}{ Juv(dead) vs Even } & $\mathrm{df}$ & 3 & 3 & 3 & 3 & 3 & 3 & 18 & 3 & 15 \\
\hline & $G$ & 37.7 & 3.5 & 14.5 & 2.1 & 6.5 & 8.8 & 76.2 & 32.2 & 40.9 \\
\hline & $\mathrm{p}$ & $* * *$ & ns & $* *$ & ns & ns & $*$ & $* * *$ & $* * *$ & $* * *$ \\
\hline
\end{tabular}

tively (Fig. 2). In contrast, Astroturf showed not only the highest residuals on average (Fig. 3a), but also a negative effect with the proportion of settlement reduced by 19 and $20 \%$ at night and during the daytime, respectively (Fig. 2). Examination of the contribution of each substratum to the $G$-value for the live megalopae treatments suggested that settlement on Astroturf was one of the main factors, and an a posteriori test excluding the settlement on the artificial substratum was carried out. Data (as a whole) continued to show a poor fit to the null hypothesis of passive distribution; nevertheless, pooled data showed

of live megalopae occurred mostly on complex substrata, in a similar pattern to the distribution of dead specimens (Fig. 2). Although overall patterns amongst replicates of live megalopae were highly variable, their deviations in relation to expected frequencies from the distribution of dead megalopae were consistently positive towards algae and cobble, and negative to Astroturf. As a result, the $G$-values of pooled data for day and night trials were both highly significant (Table 2), supporting the hypothesis of active habitat selection. Frequencies of live megalopae found on algae, pebbles and sand were, on average, higher than those of dead megalopae distribution by 10,10 and $1 \%$ at night, and 2, 5 and $3 \%$ during the daytime, respec- no significant difference for the nocturnal period (Table 2), suggesting that at night, differences in the settlement pattern in relation to the distribution of dead megalopae occurred mainly on Astroturf.

When the diel component was tested, the distribution of live megalopae was significantly affected by the time of day (Table 3), and results from mean residuals suggested that the net response on complex substrata (algae, pebbles and Astroturf) tended to be lower during daytime than at nighttime (Fig. 3a). Once more, Astroturf was the largest contributor to the $G$-value, and the pooled data from the analysis with Astroturf excluded indicated no difference in the pattern of settlement due to time of day (Table 3). megalopae

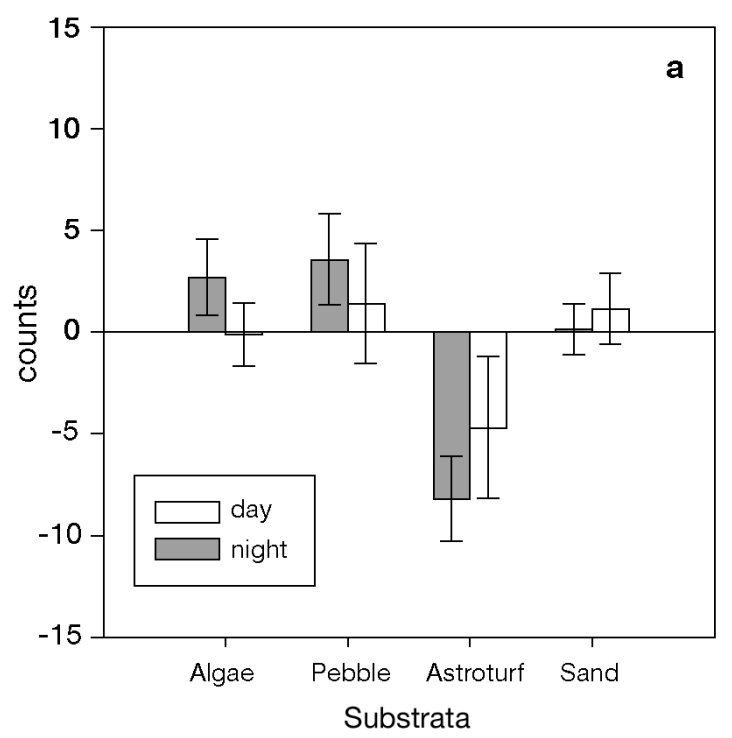

megalopae and juveniles

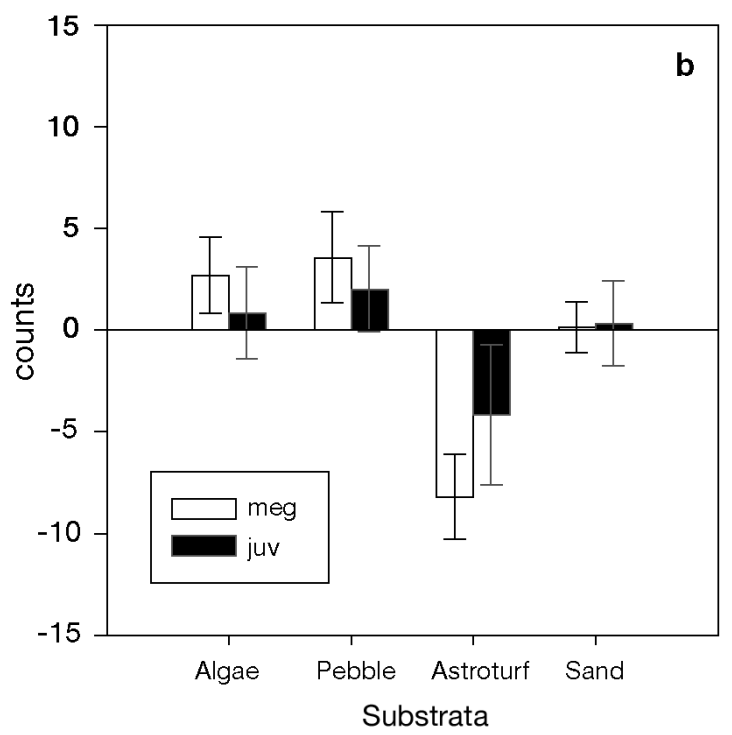

Fig. 3. Necora puber. Mean net response (counts from live animal minus counts from dead animal trials) of (a) megalopae during daytime and nighttime, and (b) megalopae (meg) and juveniles (juv) from nighttime $( \pm$ SEM) 
Table 2. Necora puber. Summary of replicated goodness-of-fit tests (Sokal \& Rohlf 1995) to test the hypothesis of active substratum selection. Data were $(x+1)$-transformed to remove zeros. Each replicate was tested separately, followed by the test of all data $\left(G_{\text {Total }}\right)$, pooled data $\left(G_{\mathrm{Pool}}\right)$, and the test of heterogeneity $\left(G_{\mathrm{Het}}\right)$. The distributions of Meg(day) = live megalopae during daytime, Meg(night) = live megalopae during nighttime, Juv(night) = live juveniles during nighttime were tested against the extrinsic hypotheses of Meg(dead) = dead megalopae and Juv(dead) = dead juveniles. ${ }^{*} \mathrm{p}<0.05,{ }^{* *} \mathrm{p}<0.01,{ }^{* * *} \mathrm{p}<0.001, \mathrm{~ns}$ : $\mathrm{p}>0.05$. Corrected probability values for substratum-excluded test are: ${ }^{*} p<0.025,{ }^{* *} p<0.01$, ns: $p>0.025$

\begin{tabular}{|c|c|c|c|c|c|c|c|c|c|c|}
\hline \multirow{2}{*}{ Distribution } & & \multicolumn{6}{|c|}{ - Replicates } & \multirow{2}{*}{$G_{\text {Total }}$} & \multirow{2}{*}{$G_{\text {Pool }}$} & \multirow{2}{*}{$G_{\text {Het }}$} \\
\hline & & 1 & 2 & 3 & 4 & 5 & 6 & & & \\
\hline \multirow{4}{*}{ Meg(day) vs Meg(dead) } & df & 3 & 3 & 3 & 3 & 3 & 3 & 18 & 3 & 15 \\
\hline & $G$ & 4.0 & 18.4 & 11.8 & 0.7 & 9.1 & 18.1 & 62 & 20.4 & 41.6 \\
\hline & $\mathrm{p}$ & ns & ${ }^{* * *}$ & ${ }^{*}$ & $\mathrm{~ns}$ & ${ }^{* *}$ & $* * *$ & $* * *$ & ${ }^{* *}$ & $* * *$ \\
\hline & $\mathrm{df}$ & 3 & 3 & 3 & 3 & 3 & 3 & 18 & 3 & 15 \\
\hline \multirow[t]{3}{*}{ Meg(night) vs Meg(dead) } & $G$ & 21.4 & 5.6 & 12.4 & 22.6 & 2.8 & 18.3 & 82.7 & 48 & 34.7 \\
\hline & $\mathrm{p}$ & ${ }^{* * *}$ & $\mathrm{~ns}$ & $* * *$ & $* * *$ & ns & ${ }^{* *}$ & $* * *$ & $* * *$ & ${ }^{* * *}$ \\
\hline & df & 3 & 3 & 3 & 3 & 3 & 3 & 18 & 3 & 15 \\
\hline \multirow[t]{2}{*}{ Juv(night) vs Juv(dead) } & $G$ & 4 & 1.0 & 3.4 & 0.6 & 9.8 & 10.0 & 33.3 & 11.4 & 21.8 \\
\hline & $\mathrm{p}$ & $*$ & $\mathrm{~ns}$ & $\mathrm{~ns}$ & ns & * & ${ }^{*}$ & * & ${ }^{*}$ & $\mathrm{~ns}$ \\
\hline \multicolumn{11}{|l|}{ Astroturf excluded } \\
\hline & $\mathrm{df}$ & 2 & 2 & 2 & 2 & 2 & 2 & 12 & 2 & 10 \\
\hline \multirow[t]{3}{*}{ Meg(day) vs Meg(dead) } & $G$ & 3.7 & 4.4 & 4.2 & 0.6 & 8.5 & 12.8 & 35.2 & 8.5 & 25.7 \\
\hline & $\mathrm{p}$ & ns & ns & ns & ns & ${ }^{* *}$ & ${ }^{* *}$ & ${ }^{* *}$ & ${ }^{*}$ & ${ }^{* *}$ \\
\hline & $\mathrm{df}$ & 2 & 2 & 2 & 2 & 2 & 2 & 12 & 2 & 10 \\
\hline \multirow[t]{3}{*}{ Meg(night) vs Meg(dead) } & $G$ & 0.6 & 1.3 & 8.9 & 16.7 & 1.1 & 1.7 & 29.7 & 5.8 & 23.8 \\
\hline & $\mathrm{p}$ & ns & ns & ${ }^{*}$ & ${ }^{* *}$ & $\mathrm{~ns}$ & ns & ${ }^{* *}$ & ns & $* *$ \\
\hline & df & 2 & 2 & 2 & 2 & 2 & 2 & 12 & 2 & 10 \\
\hline \multirow[t]{2}{*}{ Juv(night) vs Juv(dead) } & $G$ & 3.3 & 0.4 & 2.1 & 0.5 & 2.6 & 5.0 & 14.0 & 0.8 & 13.2 \\
\hline & $\mathrm{p}$ & ns & ns & ns & ns & ns & ns & ns & $\mathrm{n}$ & ns \\
\hline
\end{tabular}

Results from the juvenile treatments were similar to those from the megalopae. Dead animals were dispersed non-evenly (Table 1), and the distribution of live juve-

Table 3. Necora puber. Summary of replicated goodness-of-fit tests (Sokal \& Rohlf $1995)$ to test the hypothesis of diel variation in substratum selection. Data were $(x+1)$-transformed to remove zeros. Each replicate was tested separately, followed by the test of all data $\left(G_{\text {Total }}\right)$, pooled data $\left(G_{\text {Pool }}\right)$, and the test of heterogeneity $\left(G_{\mathrm{Het}}\right)$. The distributions of Meg(night) = live megalopae during nighttime were tested against the extrinsic hypothesis of Meg(day) = live megalopae during daytime. ${ }^{*} \mathrm{p}<0.05,{ }^{* *} \mathrm{p}<0.01,{ }^{* * *} \mathrm{p}<0.001, \mathrm{~ns}: \mathrm{p}>0.05$. Corrected probability values for substratum-excluded test are: ${ }^{*} p<0.025,{ }^{* *} p<0.01$, ns: $p>0.025$

\begin{tabular}{|c|c|c|c|c|c|c|c|c|c|c|}
\hline \multirow[t]{2}{*}{ Distribution } & & \multirow{2}{*}{1} & \multicolumn{5}{|c|}{ — Replicates } & \multirow[t]{2}{*}{$G_{\text {Total }}$} & \multirow[t]{2}{*}{$G_{\text {Pool }}$} & \multirow[t]{2}{*}{$G_{\text {Het }}$} \\
\hline & & & 2 & 3 & 4 & 5 & 6 & & & \\
\hline & $\mathrm{df}$ & 3 & 3 & 3 & 3 & 3 & 3 & 18 & 3 & 15 \\
\hline \multirow{2}{*}{ Meg(night) vs Meg(day) } & $G$ & 11.8 & 3.7 & 8.8 & 13.1 & 1.5 & 9.5 & 47.8 & 13.2 & 34.6 \\
\hline & $\mathrm{p}$ & ${ }^{* *}$ & $\mathrm{~ns}$ & ${ }^{*}$ & ${ }^{* *}$ & ns & ${ }^{*}$ & $* * *$ & ${ }^{* *}$ & $* * *$ \\
\hline \multicolumn{11}{|l|}{ Astroturf excluded } \\
\hline \multirow{3}{*}{ Meg(night) vs Meg(day) } & $\mathrm{df}$ & 2 & 2 & 2 & 2 & 2 & 2 & 12 & 2 & 10 \\
\hline & $G$ & 1.0 & 3.2 & 7.8 & 11.9 & 1.5 & 0.8 & 26.2 & 2.3 & 23.8 \\
\hline & $\mathrm{p}$ & ns & ns & * & $* *$ & ns & ns & * & ns & ${ }^{* *}$ \\
\hline
\end{tabular}

niles differed significantly from the distribution of dead juveniles. Replicates were homogeneous and supported the hypothesis of active substrata selection (Table 2).

However, when the analysis was carried out excluding Astroturf, no significant difference was found in any replicate nor on the total and pooled data (Table 2). With reference to differences due to developmental stages, the pattern of deposition of dead megalopae was significantly different from that of dead juveniles (Table 4). Deposition of dead megalopae was, on average, 8 and $5 \%$ higher than of dead juveniles on algae and Astroturf, and 7 and $6 \%$ lower on pebbles and sand, respectively (Fig. 4). The pattern for live animals was similar, and distribution of live juveniles was significantly different from that of live megalopae (night trials only) (Table 4). Megalopae settled in higher numbers on alga compared 
Table 4. Necora puber. Summary of replicated goodness-of-fit tests (Sokal \& Rohlf 1995) to test the hypothesis of ontogenetic change in substratum selection. Data were $(x+1)$-transformed to remove zeros. Each replicate was tested separately, followed by the test of all data $\left(G_{\text {Total }}\right)$, pooled data $\left(G_{\text {Pool }}\right)$, and the test of heterogeneity $\left(G_{\text {Het }}\right)$. The distributions of Juv $($ dead $)=$ dead juveniles and Juv(night) = live juveniles during nighttime were tested against the extrinsic hypotheses of Meg(dead) = dead megalopae and $\operatorname{Meg}($ night $)=$ live megalopae during nighttime. ${ }^{*} \mathrm{p}<0.05,{ }^{* *} \mathrm{p}<0.01,{ }^{* * *} \mathrm{p}<0.001, \mathrm{~ns}$ : $\mathrm{p}>0.05$. Corrected probability values for substratum-excluded test are: ${ }^{*} \mathrm{p}<0.025,{ }^{* *} \mathrm{p}<0.01$, ns: $\mathrm{p}>0.025$

\begin{tabular}{|c|c|c|c|c|c|c|c|c|c|c|}
\hline \multirow{2}{*}{ Distribution } & & \multicolumn{6}{|c|}{ — Replicates - } & \multirow{2}{*}{$G_{\text {Total }}$} & \multirow{2}{*}{$G_{\text {Pool }}$} & \multirow[t]{2}{*}{$G_{\text {Het }}$} \\
\hline & & 1 & 2 & 3 & 4 & 5 & 6 & & & \\
\hline \multirow{3}{*}{ Juv(dead) vs Meg(dead) } & $\mathrm{df}$ & 3 & 3 & 3 & 3 & 3 & 3 & 18 & 3 & 15 \\
\hline & $G$ & 11.7 & 25.9 & 4.9 & 22.5 & 5.7 & 6.1 & 76.8 & 35.8 & 41.0 \\
\hline & $\mathrm{p}$ & ${ }^{* *}$ & $* * *$ & ns & $* * *$ & ns & $\mathrm{ns}$ & ${ }^{* * *}$ & $* * *$ & $* * *$ \\
\hline \multirow{3}{*}{ Juv(night) vs Meg(night) } & $\mathrm{df}$ & 3 & 3 & 3 & 3 & 3 & 3 & 18 & 3 & 15 \\
\hline & $G$ & 0.9 & 12.9 & 11.6 & 10.0 & 16.4 & 3.9 & 55.8 & 35.2 & 20.6 \\
\hline & $\mathrm{p}$ & ns & ${ }^{* *}$ & ${ }^{* *}$ & ${ }^{*}$ & $* * *$ & ns & $* * *$ & $* * *$ & $* *$ \\
\hline \multicolumn{11}{|l|}{ Sand excluded } \\
\hline & $\mathrm{df}$ & 2 & 2 & 2 & 2 & 2 & 2 & 12 & 2 & 10 \\
\hline \multirow{2}{*}{ Juv(night) vs Meg(night) } & $G$ & 0.2 & 11.1 & 6.0 & 6.1 & 0.4 & 4.0 & 28.0 & 14.6 & 13.4 \\
\hline & $\mathrm{p}$ & ns & ${ }^{* *}$ & ns & ns & ns & $\mathrm{ns}$ & ${ }^{* *}$ & $* *$ & $\mathrm{~ns}$ \\
\hline
\end{tabular}

to juveniles, whereas juveniles were found in a higher proportion on pebble, Astroturf and particularly on sand than megalopae (Fig. 5). Differences in settlement proportion on sand and algae produced the highest contributions to the $G$-value of pooled data, 17.0 and 9.5, respectively. Thus, a posteriori analysis was carried out excluding results from settlement on sand. Replicates became homogeneous and differences remained significant (Table 4), indicating that settlement of megalopae on algae was significantly higher than for juveniles.

\section{DISCUSSION}

It has been proposed that finding and remaining in sheltered areas after settling should maximise subsequent survival, particularly in megalopae and juveniles of crabs (e.g. Eggleston \& Armstrong 1995, Pile et al. 1996, Luppi et al. 2001, Moksnes 2002). Our results show that selection of sheltered habitats by early benthic stages can occur on a small spatial scale $(<1 \mathrm{~m})$ under the influence of flow.

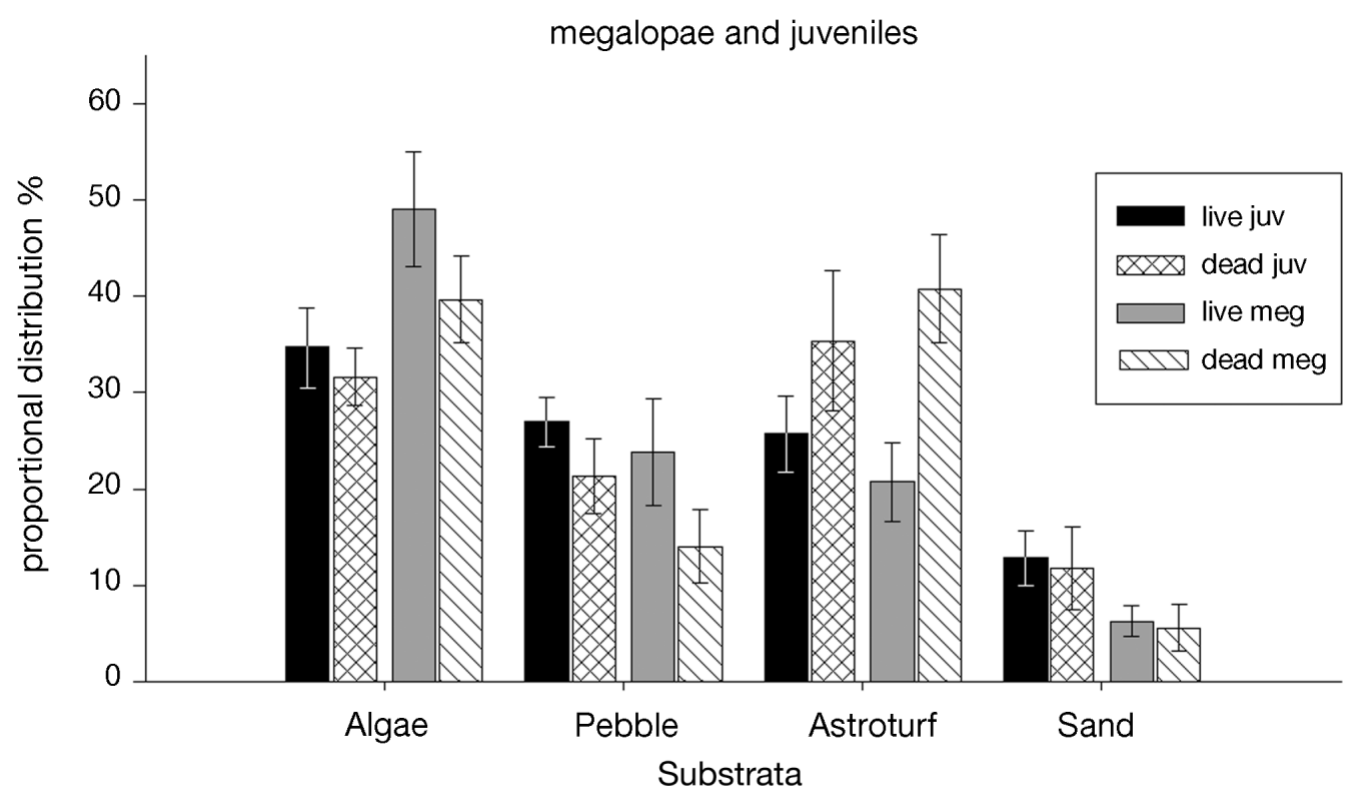

Fig. 4. Necora puber. Mean proportion of live juveniles (juv), dead juveniles, live megalopae (meg), and dead megalopae. Only night trials are included $( \pm$ SEM) 


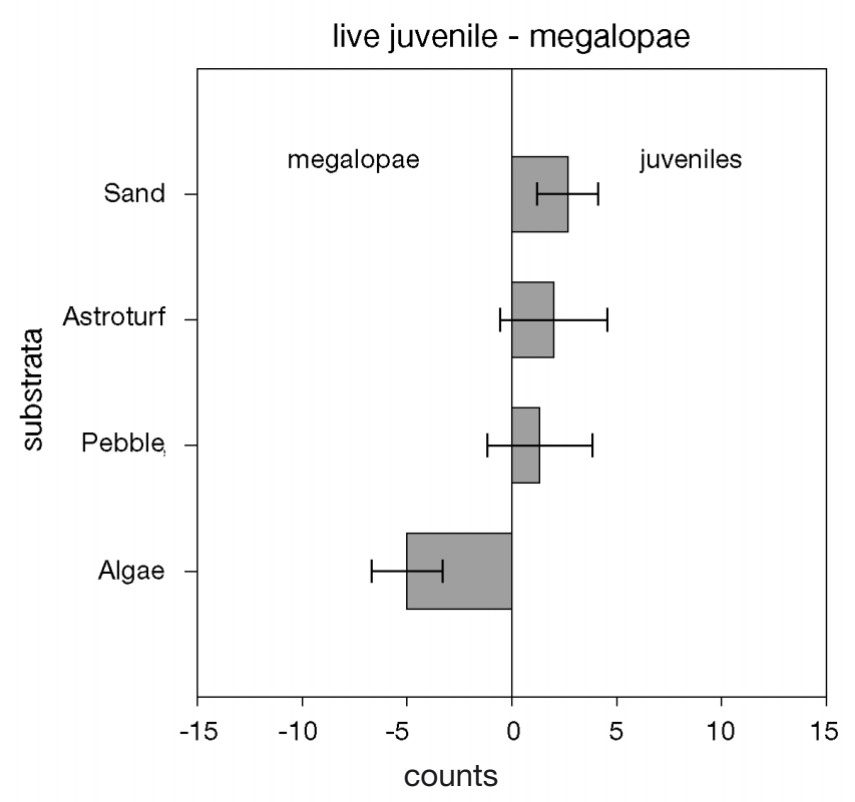

Fig. 5. Necora puber. Mean change in distribution due to developmental stage (counts from live juveniles minus counts from live megalopae trials) $( \pm$ SEM)

\section{Megalopal settlement}

Our observations of dead megalopae demonstrated that hydrodynamics produce a non-even distribution, with higher settlement on complex habitats; we refer to this as passive settlement. No dead megalopae were observed to re-suspend in the water column once movement ceased. It was possible that secondary transport after the dead megalopae have reached the sand section caused a proportion of the megalopae to be carried away to other substrata. Therefore, the numbers deposited on the sand section should be viewed as conservative values, and the mean net response of live megalopae toward sand could be lower. Our results on passive dispersal of megalopae differ from the experiments carried out at a lower current velocity $\left(3 \mathrm{~cm} \mathrm{~s}^{-1}\right)$ by Hedvall et al. (1998). The difference in the outcomes could have been a result of a combination of the differential turbulence caused by the higher current velocity used in the present study and the difference in flume size $(5.3 \mathrm{~m}$ compared to $1.7 \mathrm{~m}$ circumference in our study). In our study, a dead megalopa would have been transported, on average, for $120 \mathrm{~cm}$ (average sinking rate of $1 \mathrm{~cm} \mathrm{~s}^{-1}$ ), thus covering an average of 2 substrata. In Hedvall et al.'s (1998) work, megalopae would have been transported for $115 \mathrm{~cm}$ on average (sinking rate $1.3 \mathrm{~cm} \mathrm{~s}^{-1}$ ), covering 1 substratum $(47 \mathrm{~cm})$ and 1 transition section $(87 \mathrm{~cm})$. In addition to initial patterns set by passive deposition, we observed that differential distribution amongst substrata could be exacerbated by an active component of the settlers. Evidence for such a mechanism included the significant difference between settlement frequencies of live and dead megalopae, in particular the results from pooled data, which showed that, despite the large variability amongst replicates, the overall difference was highly significant. Whilst the net response (residuals) on algae and pebble was, on average, positive, the opposite response of megalopae towards Astroturf occurred, where an active avoidance was observed (Fig. 3a). This result indicated that most of the increase in settlement on algae and pebble, in relation to passive dispersal, was caused by movement away from Astroturf by some megalopae. Despite the structural architecture that allowed individuals to be deposited passively and remain in the tufts of fibres, Astroturf caused a negative effect, either inhibiting settlement or lacking the cues to stimulate permanence of the animals.

The lack of chemical or biological cues on Astroturf suggests that inhibition by some waterborne cue seems unlikely; however, surface rugosity could have played a role in the avoidance of Astroturf. Hacker \& Steneck (1990) reported a preference for rugose surface among artificial algal mimics of similar spatial and structural architectures for the amphipod Gamarellus angulosus. While Astroturf has a complex structure, its surface is very smooth and could be influencing tenacity (ability to grasp) of the postlarvae. This was observed during counting, when megalopae were removed easily by shaking the Astroturf mat, whilst the alga required vigorous shaking to displace crabs.

Alternatively, we suggest that spatial complexity of the habitat, and its refuge value against predators, was influencing the behaviour of megalopae to remain in the substratum. Bartholomew et al. (2000) demonstrated that predator success on the amphipod Gammarus mucronatus increased with increase of the ratio of inter-structural space size to predator size. The megalopae of the shore crab Carcinus maenas, although settling in higher proportions on macroalgae than on open sand, seemed to avoid the most 3D complex alga (Hedvall et al. 1998). This macroalga (Entocarpus siluculosus) produced poor refuges under enhanced predation conditions (Moksnes et al. 1998), and it was suggested that megalopae actively selected complex habitats that provided good refuge against predation (for other examples see Heck \& Crowder 1991). In our experiment, Astroturf could have been less attractive to settlers than the structurally less complex pebble habitat, due to structural dimensions of the tufts, just $2 \mathrm{~cm}$ height, compared to pebbles, where megalopae could be well protected in the interstices amongst the pebbles. Nonetheless, Astroturf must provide some level of protection against predation, as total numbers settling were high, and field studies have 
shown that it collects similar numbers of postlarvae of the American lobster Homarus americanus and the rock crab Cancer irroratus with natural cobble habitats (Palma et al. 1998).

In the laboratory, active habitat selection has been demonstrated for postlarvae of a number of decapod species (Fernandez et al. 1993, Hedvall et al. 1998, Stevens 2003). In these studies, the hydrodynamical conditions were relatively slower than the known swimming capacity of the postlarvae. In the work presented here, the megalopae could swim against the current for only brief periods of time; overall, flow exceeded their swimming capabilities. Literature on weak swimming larvae suggests that when larvae are faced with water movement greater than their horizontal swimming speed, a passive process drives substratum selection (see references in Butman 1987, Abelson \& Denny 1997). For example, in the larvae of the abalone Haliotis rufescens, as current velocity increased above a threshold, larvae acted increasingly like a passive particle (Boxshall 2000). In our work, megalopae actively selected among the habitats and a possible mechanism utilized by the megalopae of Necora puber to overcome the delivery to an unfavourable substratum in flow conditions would be the desertion of the substratum rather than an active exploration, as suggested by the negative net response to Astroturf; an active selection could occur once an appropriate habitat is encountered. This active selection supports evidence from recent field studies that selective settlement is a major determinant of distribution of megalopae of the portunid crabs Carcinus maenas (Moksnes 2002) and Callinectes sapidus (van Montfrans et al. 2003).

As pointed out by Butman (1987), active habitat selection and passive deposition of larvae need not be considered mutually exclusive, and could be operating at different scales of time or space. The implications of this finding are that, under hydrodynamic forces higher than the settler's swimming capability, dispersal is a passive mechanism, while active selection of substratum is possible when a less suitable substratum is encountered. Hence, the proposed mechanism of differential settlement caused by the desertion of an unfavourable site, rather than exploration and active selection of an appropriate site (Abelson \& Denny 1997), must be taking place.

The diel settlement pattern of megalopae also showed a significant difference, with a net response (residuals) towards the complex substrata tending to be stronger at night, in particular on the level of avoidance of Astroturf. Conversely, during day trials, settlement on complex substrata tended to be less specific, i.e. less selective and closer to the passive deposition (mean residuals closer to zero, Fig. 3a). Overall, lower selectivity by megalopae during the day-time is similar to that described in the field for megalopae of the shore crab Carcinus maenas (Moksnes 2003). Moksnes (2003) observed that megalopae were found in the plankton in higher numbers at night, whereas benthic megalopae were more abundant during the day, and many remained in a poor habitat until dusk before emigrating. The adaptive value of this behaviour is thought to be related to the high predation risks in the plankton during day-light, and such a strategy is evidenced in juveniles of the brown tiger shrimp Penaeus esculentus, whose diel activity pattern of burrowing during day-time, and actively swimming and feeding at night, reduced predation rates by fish (Laprise \& Blaber 1992).

\section{Early juvenile settlement and ontogenetic change in distribution}

Settlement of live juveniles was different from the passive distribution of dead animals, and similar to the pattern found in megalopae; most of the contribution to the $G$-value was due to a negative effect of Astroturf (Fig. 3b). Juveniles were found in higher numbers on the complex substrata, possibly in search of the refuge qualities of these habitats. The sheltering value against predation of substrata with complex architecture has been described many times for early crab juveniles (e.g. Pile et al. 1996, Loher \& Armstrong 2000, Orth \& van Montfrans 2002).

With regard to ontogenetic changes in settlement pattern, the present study found passive deposition of dead crabs to be significantly different from the mean distribution of dead megalopae, possibly due to differential hydrodynamic morphology and density between stages. As expected, the analysis comparing live individuals also showed significant difference. In this test, the residuals suggested that selectivity of substrata by early juveniles was less specific than by megalopae (Fig. 3b), and the shift in substrata 'choice' from megalopa to juvenile consisted of a reduction of settlement on algae and an overall increase in the other 3 substrata by juveniles (Fig. 5). Sheltering can be strongly affected by the interstitial space relative to prey size (Hacker \& Steneck 1990, Bartholomew et al. 2000) and, as juveniles grow, specific requirements for foraging and shelter might be shifting, which could explain the relatively lower negative effect of Astroturf compared to the megalopal response. Plasticity in the habitat requirement of early juveniles has also been observed for the shore crab Carcinus maenas (Moksnes et al. 1998).

When the largest contributor to the $G$-value (sand) was excluded from the comparison between live megalopae and juveniles, pooled data continued to 
show significant differences amongst the distribution of megalopae and juveniles, suggesting that the second highest contributor to the $G$-value (algae) was also responsible for the significant differences in frequencies; this further supports the possibility that an ontogenetic change in habitat use is initiated early in the early benthic instars. An ontogenetic shift of habitat use by early juvenile instars has been observed for the shore crab Carcinus maenas (Hedvall et al. 1998, Moksnes 2002) and the blue crab Callinectes sapidus (Pardieck et al. 1999, Etherington \& Eggleston 2000). In the latter, active post-settlement dispersal has been shown in early juveniles through planktonic movement (Blackmon \& Eggleston 2001).

High density has been evoked as a strong influence in the distribution of early juveniles of Callinectes sapidus in nature (Pile et al. 1996, Moksnes et al. 1997, Pardieck et al. 1999, Etherington \& Eggleston 2000, van Montfrans et al. 2003), causing dispersal by density-dependent agonistic interactions and/or cannibalism. In the trials, the high numbers of individuals necessary for the statistical tests meant that the density used was much higher than that encountered in the field, and cannibalistic and agonistic behaviours could have pressured animals for a more even distribution. However, the impact of cannibalism was apparently small, as recovery rates were high. Occasionally, animals were observed settling within $1 \mathrm{~cm}$ of each other, and densities as high as 20 juveniles per section ( $>1000$ ind. $\mathrm{m}^{-2}$ ) were observed on the algal section during the trials; thus, movement due to agonistic interaction must have been on the scale of $\mathrm{cm}$.

Habitat-specific predation of early instars is commonly regarded as a factor structuring populations (e.g. Pile et al. 1996, Etherington \& Eggleston 2000, Heck et al. 2001, Orth \& van Montfrans 2002). Nonetheless, this is not always the case, as demonstrated recently for a population of Carcinus maenas in Sweden (Moksnes 2002) where high predation rates caused great changes in abundance, but not in the pattern of distribution of young juveniles. Thus, it is not clear to what extent predation could be responsible for the formation of patchy distribution of juveniles of Necora puber, which are found mainly under cobbles and pebbles (Choy 1986, Norman 1989, Hearn 2001, J. T. Lee unpubl. data).

In summary, our findings suggest that megalopae of Necora puber actively select substrata of higher structural complexity, particularly during the nocturnal period. This initial pattern of distribution is soon changed by post-settlement movement of early juvenile instars, which have different habitat requirements and are generally less selective. Our conclusions, however, are limited by the spatial (metres) and the temporal scale (less then $12 \mathrm{~h}$ ) of this study. We suggest that post-settlement migration of juveniles at larger spatial and temporal scales, and refuge from predation, should play an important role in the distribution of subsequent instars. Further work should focus on understanding the mechanisms involved in the stimuli towards the preferred substrata under larger temporal scales and the impact of predation pressure on the behaviour demonstrated by the early benthic stages, as these would certainly affect the patterns observed.

Acknowledgements. This work was funded by a CNPq (Brazil) studentship to J.T.L. The authors would like to thank Stephen Roast for help with the flume and a draft of Fig. 1. We are also grateful to Richard Ticehurst and Anne Torr for technical assistance. This manuscript was greatly improved by comments from Per-Olav Moksnes and 2 anonymous referees.

\section{LITERATURE CITED}

Abelson A, Denny M (1997) Settlement of marine organisms in flow. Annu Rev Ecol Syst 28:317-339

Alvarez-Ossorio MT, Valdes L, Gonzalez-Gurriaran E (1990) Effects of several diets on larval development of Necora puber (L., 1767). Bol Inst Esp Oceanogr 6:73-80

Bartholomew A, Diaz RJ, Cicchetti G (2000) New dimensionless indices of structural habitat complexity: predicted and actual effects on a predator's foraging success. Mar Ecol Prog Ser 206:45-58

Blackmon DC, Eggleston DB (2001) Factors influencing planktonic, post-settlement dispersal of early juvenile blue crabs (Callinectes sapidus Rathbun). J Exp Mar Biol Ecol 257: 183-203

Booth JD (2001) Habitat preferences and behaviour of newly settled Jasus edwardsii (Palinuridae). Mar Freshw Res 52: 1055-1075

Boxshall AJ (2000) The importance of flow and settlement cues to larvae of the abalone, Haliotis rufescens Swainson. J Exp Mar Biol Ecol 254:143-167

Butman CA (1987) Larval settlement of soft-sediment invertebrates: the spatial scales of pattern explained by active habitat selection and the emerging role of hydrodynamical processes. Oceanogr Mar Biol Annu Rev 25:113-165

Choy SC (1986) Ecological studies on Liocarcinus puber (L.) and L. holsatus (Fabricius) (Crustacea, Brachyura, Portunidae) around the Gower Peninsula, South Wales. PhD thesis, University of Wales

Choy SC (1988) Reproductive biology of Liocarcinus puber and L. holsatus (Decapoda, Brachyura, Portunidae) from the Gower Peninsula, South Wales. PSZN I: Mar Ecol 9:227-241

Choy SC (1991) Embryonic and larval biology of Liocarcinus holsatus and Necora puber (Crustacea: Brachyura: Portunidae). J Exp Mar Biol Ecol 148:77-92

Cobb JS, Wahle RA (1994) Early-life history and recruitment processes of clawed lobsters. Crustaceana 67:1-25

Cobb JS, Wang DB, Campbell DB, Rooney P (1989) Speed and direction of swimming of postlarvae of the American lobster. Trans Am Fish Soc 118:82-86

Cobb JS, Booth JD, Clancy M (1997) Recruitment strategies in lobsters and crabs: a comparison. Mar Freshw Res 48: 797-806

Diaz H, Orihuela B, Forward RB, Rittschof D (1999) Orientation of blue crab, Callinectes sapidus (Rathbun), Mega- 
lopae: responses to visual and chemical cues. J Exp Mar Biol Ecol 233:25-40

Eggleston DB, Armstrong DA (1995) Pre- and post-settlement determinants of estuarine Dungeness crab recruitment. Ecol Mongr 65:193-216

Etherington LL, Eggleston DB (2000) Large-scale blue crab recruitment: linking postlarval transport, post-settlement planktonic dispersal, and multiple nursery habitats. Mar Ecol Prog Ser 204:179-198

Fernandez M, Iribarne O, Armstrong D (1993) Habitat selection by young-of-the-year Dungeness crab Cancer magister and predation risk in intertidal habitats. Mar Ecol Prog Ser 92:171-177

Fernandez M, Iribarne O, Armstrong DA (1994) Swimming behavior of dungeness crab, Cancer magister Dana, megalopae in still and moving water. Estuaries 17:271-275

Forward RB Jr, Tankersley RA (2001) Selective tidal-stream transport of marine animals. Oceanogr Mar Biol Annu Rev 39:305-353

Forward RB Jr, Tankersley RA, Smith KA, Welch JM (2003) Effects of chemical cues on orientation of blue crab, Callinectes sapidus, megalopae in flow: implications for location of nursery areas. Mar Biol 142:747-756

Freire J, Sampedro MP, Gonzalez-Gurriaran E (1996) Influence of morphometry and biomechanics on diet selection in three portunid crabs. Mar Ecol Prog Ser 137:111-121

Fukada MK, Lick W (1980) The entrainment of cohesive sediment in freshwater. J Geophys Res 85:2813-2824

Gonzalez-Gurriaran E (1985a) Crecimiento de la nécora Macropipus puber (L.) (Decapoda, Brachyura) en la Ría de Arousa (Galicia, NW España), y primeros datos sobre la dinámica de la población. Bol Inst Esp Oceanogr 2:33-51

Gonzalez-Gurriaran E (1985b) Reproducción de la nécora Macropius puber (L.) (Decapoda, Brachyura), y ciclo reproductivo en la Ría de Arousa (Galicia, NW España). Bol Inst Esp Oceanogr 2:10-32

Gonzalez-Gurriaran E, Freire J, Fernandez L (1995) Feeding activity and contribution of mussel raft culture in the diet of crabs in the Ria de Arousa (Galicia, northwest Spain). ICES Mar Sci Symp 199:99-107

Gosselin LA, Qian PY (1997) Juvenile mortality in benthic marine invertebrates. Mar Ecol Prog Ser 146:265-282

Hacker SD, Steneck RS (1990) Habitat architecture and the abundance and body-size-dependent habitat selection of a phytal amphipod. Ecology 71:2269-2285

Hearn A (2001) The biology and fishery of the velvet swimming crab, Necora puber (L.) (Brachyura, Portunidae) in the Orkney Islands, UK. PhD thesis, Heriot-Watt University

Heck KL Jr, Crowder LB (1991) Habitat structure and predator-prey interactions in vegetated aquatic systems. In: Bell SS, McCoy ED, Mushinsky HR (eds) Habitat structure: the physical arrangement of objects in space. Chapman \& Hall, London, p 281-299

Heck KL, Coen LD, Morgan SG (2001) Pre- and post-settlement factors as determinants of juvenile blue crab Callinectes sapidus abundance: results from the north-central Gulf of Mexico. Mar Ecol Prog Ser 222:163-176

Hedvall O, Moksnes PO, Pihl L (1998) Active habitat selection by megalopae and juvenile shore crabs Carcinus maenas: a laboratory study in an annular flume. Hydrobiologia 375/376:89-100

Hiscock S (1986) A field guide to the British red seaweeds (Rhodophyta). Field Studies Council, Preston Montford

Hunt HL, Scheibling RE (1997) Role of early post-settlement mortality in recruitment of benthic marine invertebrates. Mar Ecol Prog Ser 155:269-301

Incze LS, Wahle RA (1991) Recruitment from pelagic to early benthic phase in lobsters Homarus americanus. Mar Ecol Prog Ser 79:77-87

Ingle RW (1983) Shallow-water crabs, Vol 25. Cambridge University Press, Cambridge

Jensen GC (1989) Gregarious settlement by megalopae of the porcelain crabs Petrolisthes cinctipes (Randall) and P. eriomerus Stimpson. J Exp Mar Biol Ecol 131:223-231

Jensen GC (1991) Competency, settling behavior, and postsettlement aggregation by porcelain crab megalopae (Anomura: Porcellanidae). J Exp Mar Biol Ecol 153:49-61

Laprise R, Blaber SJM (1992) Predation by Moses perch, Lutjanus russelli, and blue-spotted trevally, Caranx bucculentus, on juvenile brown tiger prawn, Penaeus esculentus: effects of habitat structure and time of day. J Fish Biol 40:627-635

Lebour MV (1928) The larval stages of the Plymouth Brachyura. Proc Zool Soc Lond 2:473-560

Lebour MV (1947) Notes on the inshore plankton of Plymouth. J Mar Biol Assoc UK 26:527-547

Lindley JA (1986) Vertical distributions of decapod crustacean larvae and pelagic postlarvae over Great Sole Bank (Celtic Sea) in June 1983. Mar Biol 90:545-549

Lindley JA (1987) Continuous plankton records: the geographical distribution and seasonal cycles of decapod crustacean larvae and pelagic post-larvae in the northeastern Atlantic Ocean and North Sea, 1981-3. J Mar Biol Assoc UK 67:145-167

Linnane A, Mazzoni D, Mercer JP (2000) A long-term mesocosm study on the settlement and survival of juvenile European lobster Homarus gammarus L. in four natural substrata. J Exp Mar Biol Ecol 249:51-64

Loher T, Armstrong DA (2000) Effects of habitat complexity and relative larval supply on the establishment of early benthic phase red king crab (Paralithodes camtschaticus Tilesius, 1815) populations in Auke Bay, Alaska. J Exp Mar Biol Ecol 245:83-109

Luckenbach MW, Orth RJ (1992) Swimming velocities and behavior of blue crab (Callinectes sapidus Rathbun) megalopae in still and flowing water. Estuaries 15:186-192

Luppi TA, Spivak ED, Anger K (2001) Experimental studies on predation and cannibalism of the settlers of Chasmagnathus granulata and Cyrtograpsus angulatus (Brachyura: Grapsidae). J Exp Mar Biol Ecol 265:29-48

Mene L, Alvarez-Ossorio MT, Gonzalez-Gurriaran E, Valdes L (1991) Effects of temperature and salinity on larval development of Necora puber (Brachyura: Portunidae). Mar Biol 108:73-81

Moksnes PO (2002) The relative importance of habitatspecific settlement, predation and juvenile dispersal for distribution and abundance of young juvenile shore crabs Carcinus maenas L. J Exp Mar Biol Ecol 271:41-73

Moksnes PO (2003) Settlement behavior in shore crabs Carcinus maenas: why do postlarvae emigrate from nursery habitats? Mar Ecol Prog Ser 250:215-230

Moksnes PO, Lipcius RN, Pihl L, van Montfrans J (1997) Cannibal-prey dynamics in young juveniles and postlarvae of the blue crab. J Exp Mar Biol Ecol 215:157-187

Moksnes PO, Pihl L, van Montfrans J (1998) Predation on postlarvae and juveniles of the shore crab Carcinus maenas: importance of shelter, size and cannibalism. Mar Ecol Prog Ser 166:211-225

Norman CP (1989) Ecology of the velvet swimming crab Liocarcinus puber (Brachyura: Portunidae). PhD thesis, University of Plymouth

Norman CP, Jones MB (1992) Influence of depth, season and moult stage on the diet of the velvet swimming crab $\mathrm{Nec}$ ora puber (Brachyura, Portunidae). Estuar Coast Shelf Sci 34:71-83 
Norman CP, Jones MB (1993) Reproductive ecology of the velvet swimming crab, Necora puber (Brachyura: Portunidae), at Plymouth. J Mar Biol Assoc UK 73:379-389

Orth RJ, van Montfrans J (2002) Habitat quality and prey size as determinants of survival in post-larval and early juvenile instars of the blue crab Callinectes sapidus. Mar Ecol Prog Ser 231:205-213

Palma AT, Wahle RA, Steneck RS (1998) Different early postsettlement strategies between American lobsters Homarus americanus and rock crabs Cancer irroratus in the Gulf of Maine. Mar Ecol Prog Ser 162:215-225

Pardieck RA, Orth RJ, Diaz RJ, Lipcius RN (1999) Ontogenetic changes in habitat use by postlarvae and young juveniles of the blue crab. Mar Ecol Prog Ser 186:227-238

Pawlik JR (1992) Chemical ecology of the settlement of benthic marine invertebrates. Oceanogr Mar Biol Annu Rev 30:273-335

Pawlik JR, Butman CA (1993) Settlement of a marine tube worm as a function of current velocity: interacting effects of hydrodynamics and behavior. Limnol Oceanogr 38: $1730-1740$

Pile AJ, Lipcius RN, Van Montfrans J, Orth RJ (1996) Densitydependent settler-recruit-juvenile relationships in blue crabs. Ecol Mongr 66:277-300

Rittschof D, Forward RB, Cannon G, Welch JM and 7 others (1998) Cues and context: larval responses to physical and chemical cues. Biofouling 12:31-44

Sokal RR, Rohlf FJ (1995) Biometry WH Freeman, New York

Stevens BG (2003) Settlement, substratum preference, and survival of red king crab Paralithodes camtschaticus (Tilesius, 1815) glaucothoe on natural substrata in the laboratory. J Exp Mar Biol Ecol 283:63-78

Stevens BG, Kittaka J (1998) Postlarval settling behavior, substrate preference, and time to metamorphosis for red king crab Paralithodes camtschaticus. Mar Ecol Prog Ser 167: 197-206

Editorial responsibility: Roger Hughes (Contributing Editor), Bangor, UK
Underwood AJ, Fairweather PG (1989) Supply-side ecology and benthic marine assemblages. Trends Ecol Evol 4:16-20

Underwood AJ, Keough MJ (2001) Supply-side ecology: the nature and consequences of variations in recruitment of intertidal organisms. In: Bertness MD, Gaines SD, Hay ME (eds) Marine community ecology. Sinauer Associates, Sunderland, p 183-200

Valdes L, Alvarez Ossorio MT, Gonzalez Gurriaran E (1991) Influence of temperature on embryonic and larval development in Necora puber (Brachyura, Portunidae). J Mar Biol Assoc UK 71:787-798

van Montfrans J, Ryer CH, Orth RJ (2003) Substrate selection by blue crab Callinectes sapidus megalopae and the first juvenile instar. Mar Ecol Prog Ser 260:209-217

Wahle RA, Steneck RS (1991) Recruitment habitats and nursery grounds of the American lobster Homarus americanus: a demographic bottleneck? Mar Ecol Prog Ser 69:231-243

Wahle RA, Steneck RS (1992) Habitat restrictions in early benthic life: experiments on habitat selection and in situ predation with the American lobster. J Exp Mar Biol Ecol 157:91-114

Welch JM, Forward RB (2001) Flood tide transport of blue crab, Callinectes sapidus, postlarvae: behavioral responses to salinity and turbulence. Mar Biol 139:911-918

Welch JM, Rittschof D, Bullock TM, Forward RB (1997) Effects of chemical cues on settlement behavior of blue crab Callinectes sapidus postlarvae. Mar Ecol Prog Ser 154:143-153

Welch JM, Forward RB Jr, Howd PA (1999) Behavioral responses of blue crab Callinectes sapidus postlarvae to turbulence: implications for selective tidal stream transport. Mar Ecol Prog Ser 179:135-143

Widdows J, Brinsley MD, Bowley N, Barrett C (1998) A benthic annular flume for in situ measurement of suspension feeding/biodeposition rates and erosion potential of intertidal cohesive sediments. Estuar Coast Shelf Sci 46:27-38

Submitted: August 1, 2003; Accepted: February 9, 2004 Proofs received from author(s): May 12, 2004 